\title{
Karakteristik Kepemimpinan Pendidikan Islam
}

\section{Nur Raisah Ulinnuha}

Mahasiswa Pascasarjana Program Studi Pendidikan Agama Islam

Fakultas Tarbiyah Dan Ilmu Keguruan, Universitas Islam Negeri Sunan Kalijaga

nraisahulin@Gmail.Com

$\begin{array}{ll}\begin{array}{l}\text { Submission } \\ \text { Track: }\end{array} & \text { Abstract } \\ \text { Received: } & \begin{array}{l}\text { Leadership can be interpreted as a process of influencing and directing citizens or workers to do work } \\ \text { according to their duties. The fact is that in Indonesia many leaders who are wrongfully caught buying } \\ \text { and selling positions, corruption and so on. A leader must have a noble mind, because he will be a role } \\ \text { model, he who will create opportunities and provide encouragement as well as input to its members. } \\ \text { Like the Javanese language slogan from the father of education which is often promoted in the world } \\ \text { of education Ing Ngarso Sung Tulodo, Ing Madyo Mangun Karso and Tut Wuri } \\ \text { Final Revision: }\end{array} \\ \begin{array}{l}\text { Handayani. In Islam, Allah has given examples of exemplary living examples namely the Prophet } \\ \text { Mubammad who has the nature of siddiq, tabligh, trust and fathanah. The main types of Islamic } \\ \text { Available online: }\end{array} & \begin{array}{l}\text { education leadership include authoritarian leadership, free leadership and democratic leadership. While } \\ \text { complementary Islamic education leadership types include charismatic leadership types, guardian }\end{array} \\ 25 \text { September 2019 } & \begin{array}{l}\text { leadership types, expert leader types, organizational and administrator leadership types, agitator } \\ \text { leadership types. }\end{array}\end{array}$

Author:

Keywords: Leadership, Islamic Leadership

Name \& E-mail Address

Abstrak

Nur Raisah Ulinnuha

nraisahulin@gmail.com

Kepemimpinan dapat diartikan sebagai proses mempengaruhi dan mengarahkan para warga atau pekerja untuk melakukan pekerjaan sesuai tugasnya. Faktanya di Indonesia banyak pemimpin yang dzalim tertangkap tangan melakukan jual beli jabatan, korupsi dan sebagainya. Seorang pemimpin haruslah memiliki budi yang luhur, karena ia akan menjadi panutan, ia yang akan menciptakan peluang dan memberi dorongan dan masukan kepada anggotanya. Seperti semboyan berbahasa Jawa dari bapak pendidikan yang kerap digalakkan dalam dunia pendidikan Ing Ngarso Sung Tulodo, Ing Madyo Mangun Karso dan Tut Wuri Handayani. Dalam Islam, Allah sudah memberikan contoh suri tauladan hidup yaitu Rasulullah SAW yang memiliki sifat siddiq, tabligh, amanah dan fathanah. tipe kepemimpinan pendidikan Islam yang utama diantaranya tipe kepemimpinan otoriter, tipe kepemimpinan bebas dan tipe kepemimpinan demokratis. Sedangkan tipe kepemimpinan pendidikan Islam pelengkap yaitu diantaranya tipe kepemimpinan kharismatis, tipe kepemimpinan pengayom, tipe pemimpin ahli, tipe kepemimpinan organisatoris dan administrator, tipe kepemimpinan agitator.

Kata kunci : Kepemimpinan, Kepemimpinan Islam

\section{PENDAHULUAN}

Kepemimpinan tidak dapat dipisahkan dari kehidupan sosial. (Rivai dan Arifin, 2009: 142-143). Kepemimpinan menjadi sebuah profesi, bukan hasil keturunan, tetapi kemauan, kemampuan, kesanggupan, dan kecakapan seseorang untuk memahami asas kepemimpinan yang sehat, menggunakan prinsip-prinsip, sistem, metode dan teknik kepemimpinan yang sebaik-baiknya, memahami konsep dasar kepemimpinan, serta berfikir dengan seksama, mempunyai pengetahuan, pengalaman, dan mampu menyusun rencana tentang apa yang akan dilaksanakan dan tujuan yang akan dicapai (Mertoprawiro, 1996: 5)

Menurut Dirawat, kepemimpinan dalam pendidikan adalah suatu potensi dan metode mempengaruhi, mengkoordinir serta 
menggerakkan anggota organisasi dengan perkembangan ilmu pendidikan dan pelaksanaan pendidikan dan pengajaran, bertujuan pada keefisienan dan keefektifan kegiatan-kegiatan demi tercapainya tujuan pengajaran serta pendidikan (Rozak, 2014: 11).

Pada proses jalannya kepemimpinan pendidikan secara umum dilihat dari bentuk-bentuk kegiatan pemimpin memiliki karakteristik, yang diantaranya pertama merintis upaya-upaya kreatif pada aktivitas kependidikan dan pengajaran. Kedua membimbing, mengajar, memobilisasi, mengkoordinir serta memajukan kegiatan-kegiatan yang tergabung dalam lembaga yang melakukan upaya kependidikan dan pengajaran layaknya sekolah sebagai institusi pendidikan. Ketiga, merumuskan ide-ide yang baru dan segar dalam kegiatan dan penemuan-penemuan di bidang ilmu pendidikan dan pengajaran.

Untuk menjalankan kepemimpinannya, seorang pemimpin berjalan atas dasar kepercayaan dari anggotanya. Ketika rasa percaya antar anggota menjadi luntur, pimpinannya tidak lama akan runtuh. Seperti kepemimpinan dalam ranah pendidikan yang berlandaskan asas saling percaya. Karena dengan cara seperti itulah seorang pemimpin akan disegani dan dihormati dalam sebuah organisasi. Biasanya tipe kepemimpinan seseorang tergantung pada gaya orang tersebut Landasan Manajemen Pendidikan. (Nanang, 2011: 88).

Dari penjelasan di atas dapat kita pahami bahwa untuk memimpin sebuah lembaga pendidikan harus memiliki gaya atau karakteristik yang dapat memberikan keyakinan pada seluruh demi berhasilnya misi dari lembaga. Keberhasilan dan kekalahan sebuah organisasi pasti berhubungan kepemimpinan. Umumnya, peran pimpinan sebagai jembatan tercapainya misi lembaga atau institusi. Seperti pendapat Al-Ghazali yang memberikan kekuatan kepemimpinan dengan iman seperti firman Allah, "tidakeah kamu perhatikan bagaimana Allah telah membuat perumpamaan kalimat yang baik seperti pohon yang baik, akarnya teguh dan cabangnya (menjulang) ke langit." (Q.S Ibrahim; 24). Apabila akarnya rapuh tanpa iman, memiliki cabang yang sedikit maka pohon akan tercabut dari akarnya dan roboh. Mati tanpa dilandasi iman dan menghadap Tuhan tanpa kebaikan (Al-Ghazali, 1994: 30 ).

Pada kenyataannya, banyak kasus seorang pemimpin yang tidak menjaga amanah rakyat, contohnya adalah kasus Gubernur Aceh yang korupsi dan divonis penjara selama tujuh tahun (Kompas,

https:// nasional.kompas.com/read/2019/04/08/2 2375201/gubernur-aceh-irwandi-yusuf-divonis-7tahun-penjara?page $=$ all, diakses pada tanggal 28 Agustus 2019). Jual beli jabatan di kementrian agama yang dilakukan oleh mantan ketua PPP, Muhammad Rumahurmuziy dan pegawai kementrian agama di Jawa Timur (Tribun, https://www.tribunnews.com/nasional/2019/03/2 4/korupsi-korupsi-di-pusaran-kementerian-agama akses pada tanggal 28 Agustus 2019).

Ahok, mantan gubernur Jakarta yang menistakan kitab suci Al-Qur'an yang meski bukan agamanya (BBC News Indonesia, https://www.bbc.com/indonesia/berita_indonesia /2016/10/161007_indonesia_ahok_laporan) akses pada tanggal 28 Agustus 2019), kepala sekolah yang menggelapkan dana bos (Kompas, https://regional.kompas.com/read/2019/03/22/2 
2291211/korupsi-dana-bos-mantan-kepsek-danbendahara-di-bima-ditahan akses pada tanggal 28 Agustus 2019). Namun di sisi lain seorang pemimpin dilahirkan dari rahim yang berbeda, mereka memiliki paras, sikap, watak yang berbedabeda. Pembangkang, penuntut, penurut atau yang lainnya.

Seorang pemimpin haruslah memiliki budi yang luhur, karena ia akan menjadi panutan, ia yang akan menciptakan peluang dan memberi dorongan dan masukan kepada anggotanya. Seperti semboyan berbahasa Jawa dari bapak pendidikan yang kerap digalakkan dalam dunia pendidikan Ing Ngarsa Sung Tuladha, Ing Madya Mangun Karsa dan Tut Wuri Handayani. Dalam Islam, Allah sudah memberikan contoh suri tauladan hidup yaitu Rasulullah SAW yang memiliki sifat siddiq, tabligh, amanah dan fathanah.

Pada makalah ini akan dibahas mengenai gaya atau karakteristik, tipe kepemimpinan pendidikan Islam.

\section{METODE PENELITIAN}

Pada penelitian ini penulis menggunakan metode kualitatif dengan pendekatan library research. Penelitian kepustakaan (library research) merupakan penelitian yang berfungsi mendapatkan informasi dari buku, majalah, dokumen, catatan sejarah atau dengan kata lain fasilitas yang terdapat dalam perpustakaan. (Sholeh, 2005: 63).

Pendekatan kepustakaan adalah penelitian dengan kegiatan mencari data dari membaca buku dan mengolahnya, yang dalam hal ini adalah mengenai karakteristik kepemimpinan dalam pendidikan Islam. Dalam proses penelitian library reseaarch, perpustakaan menjadi tempat yang utama untuk mendapatkan data dan informasi yang relevan untuk dibaca dan dikumpulkan, dikaji dan dicatat.

\section{HASIL DAN PEMBAHASAN}

\section{Gaya Atau Karakteristik Kepemimpinan Pendidikan Islam}

Pemimpin berarti pelaku atau orang yang memimpin (Tim Penyusun Kamus Pusat Bahasa, Kamus Besar Bahasa Indonesia, 2002: 601). Kepemimpinan dalam Islam merupakan sebuah ajaran Islam yang dapat memberi sibghah (corak) dan wijhah (arah) kepada pemimpin, agar dapat merubah pemikiran atau sikap yang menghambat kemajuan dari perorangan maupun masyarakat. (Munawwir, t.th: hal. ix). Kepemimpinan Islam adalah kepemimpinan dengan mempraktekkan ajaran-ajaran Islam (Zainuddin, 2002: 16).

Untuk mengetahui keberhasilan atau kegagalan pemimpin, terlebih dulu secara simple harus dibuat bagaimana seharusnya pola tingkah seorang pemimpin. Bila ternyata keadaan itu tidak sesuai maka terjadilah kegagalan atau krisis kepemimpinan. Dalam kepemimpinan diperlukan adanya unsur pemimpin, yakni yang mempengaruhi tingkah laku pengikut-pengikutnya dalam suatu situasi. Ia mampu memberikan sibghah dan wijhah, bentuk warna dan arah, yang dilakukan dalam proses pengaruh mempengaruhi melalui komunikasi (Munawwir, t.th: hal. 14-15).

Tercapainya tujuan dalam membina dan mengembangkan suatu masyarakat, maka diperlukan pemimpin yang berkarakter sesuai dengan keperluan pada masyarakat, di antaranya:

1. Karakteristik Kepemimpinan dalam Intern golongan Islam

a. Mampu menanamkan sikap tasamuh (toleransi). 
Koreksilah dirimu sebelum engkau dikeroksi orang lain, Hassibu anfussakum qabla an tuhassabu.

b. Mampu menumbuhkan kerjasama dan solidaritas sesama ummat Islam (QS. AlMaidah:2)

c. Menerapkan fastabiqul khairat (berlombalomba dalam kebaikan)

d. Menghilangkan kultus wadah (kurang menerima kritik dan saran) atau bersikap open minded. (QS. Az-Zumar 18)

e. Mampu menciptakan tenaga pengganti dan berjiwa demokrat.

$$
\text { ليس منا من لم يرح صغيرنا }
$$

"Bukanlah termasuk golongan kami orang yang tidak menyayangi yang muda diantara kami dan tidak menghormati orang yang tua diantara kami." (HR. at Tirmidzi, dishahihkan oleh Syaikh al Albani dalam ash Shahihah no. 2196)

\section{HR Abu Daud dan At-Tirmidzi}

f. Mampu menghilangkan jabid (sikap reaksioner) dan jamid (beku dalam berfikir) di tubuh masyarakat.

2. Karakter pemimpin dalam intern ummat Islam yang memimpin golongan Islam secara keseluruhan diantaranya harus memenuhi syarat berikut (Munawwir, t.th: hal. 133-145):

a. Adil dan jujur (QS Al-Maidah: 8, Annisa: 135, An-Nahl 90

b. Bijaksana dalam menghadapi masalah

c. Berpandangan luas serta tidak fanatik golongan

d. Berwibawa dan disegani

e. Berjiwa integrasi

f. Mementingkan kepentingan ummat daripada kepentingan pribadi

Menurut Al-Ghazali dalam buku Sjadzali, kriteria pemimpin antara lain dewasa, memiliki pikiran sehat, bukan hamba sahaya, laki-laki, memiliki mata dan telinga sehat, nyata kekuasaannya, memiliki pemikiran cerdas dan kreatif, suka bermusyawarah, menerima saran dan kritik, berilmu, dapat mengendalikan diri dari perbuatan tercela. (Sjadzali, 1993: hlm. 135).

Dalam mewujudkan fungsi kepemimpinan pada tahap pertama mudah terlihat gaya kepemimpinan, kemudian mengerucut menjadi tipe-tipe kepemimpinan (Nawawi, 1993: 153). Pada hal ini secara teoritis dapat dibedakan tiga gaya kepemimpinan, yaitu:

1. Mengutamakan Pelaksanaan Tugas

Kepemimpinan ini didasari asumsi tugas pemimpin adalah memacu anggota untuk melaksanakan tugas secara maksimal. Gaya ini berpola mementingkan pelaksanaan tugas melebihi berbagai kegiatan lainnya dalam kehidupan berorganisasi.

\section{Mengutamakan Kerjasama}

Kepemimpinan ini mengutamakan kerja sama antar anggota.

3. Mengutamakan Hasil

Kepemimpinan ini mementingkan hasil akhir yang harus dicapai dalam melaksanakan pekerjaan tertentu. Pemimpin menaruh perhatian yang besar dan keinginan yang kuat untuk mencapai hasil yang maksimal.

$\begin{array}{rrr}\text { Secara } & \text { operasional, } & \text { suatu } \\ \text { kepemimpinan } & \text { berlangsung } & \text { secara }\end{array}$
bersamaan, tetapi akan menunjukkan salah satu gaya yang menonjol, tetapi ada gayagaya lain sebagai penunjang. Dalam 
keadaan seperti itu, maka gaya kepemimpinan yang terjadi secara kondisional dapat dibagi menjadi delapan, yaitu (Nawawi, 1993: 153-160):

\section{Otokrasi}

Kepemimpinan gaya ini menunjukkan kriteria antara lain:

a. Pelaksanaan kerja menjadi pokok utama

b. Kontrol kerja dilakukan secara ketat

c. Mematikan kreativitas dan inisiatif anggota organisasi

d. Kurang memperhatikan hubungan manusiawi antar pemimpin dan yang dipimpin

e. Kurang mempercayai orang lain

f. Kurang disenangi dan cenderung menghindari anggotanya

g. Menganggap anggota tidak lebih sebagai pelaksana program kerjanya

h. Sukar memberikan maaf pada anggota

i. Pendapat atau saran dari anggota dianggap sikap menantang dan membangkang

j. Anggota cenderung terpecahpecah atau berkelompok

2. Otokrasi yang Disempurnakan (Benevolent Autocrat)

Perilaku kepemimpinan dalam gaya ini menunjukkan ciri-ciri:

a. Mengutamakan pada hasil atau produktivtas yang tepat dan efektif sesuai perintah b. Mampu memetakan petunjuk dan perintah

c. Peraturan sangat ketat dan selalu mengawasi pelaksanaannya

d. Kurang yakin pada diri sendiri

3. Birokrat

a. Bekerja sesuai peraturan yang ketat dan prosedur kerja yang telah ditetapkan

b. Patuh terhadap pimpinan

c. Kepemimpinan dilaksanakan secara formal

d. Kurang aktif dan bersifat saling menunggu dalam melaksanakan tugas-tugas

e. Gagasan, inisatif dan kreativitas berorientasi pada aturan kerja

f. Kurang mengembangkan hubungan manusiawi dengan orang-orang yang dipimpin

g. Kurang menyukai masyarakat dan orang luar, karena pemimpin berkewajiban merahasiakan hal-hal yang berkaitan dengan pekerjaannya.

4. Pelindung dan penyelamat (Missionary)

a. Hubungan pemimpin dan anggota baik.

b. Meminimalisir terjadinya perdebatan.

c. Saling menghormati dan menghargai antara pemimpin dan anggota.

d. Mengutamakan pelayanan untuk kepuasan orang lain. 
5. Berorientasi pada kemajuan dan pengembangan organisasi

Karakteristik dari memajukan dan mengembangkan organisasi adalah sebagai berikut :

a. Lincah berorganisasi

b. Mampu mengorganisir anggota secara efektif, efisien dan bertanggung jawab

c. Memiliki rasa saling percaya antar anggota

d. Hubungan harmonis antara pemimpin dan anggota.

6. Eksekutif (Pelaksana)

Ciri-ciri gaya kepemimpinan eksekutif antara lain :

a. Percaya dan memiliki mindset bahwa anggota mampu menyeleseaikan pekerjaan secara maksimal

b. Mengutamakan kualitas pekerjaan

c. Bekerja secara efektif dan efisien

d. Menerima kritik dan saran.

7. Kompromi (Compromiser)

Ciri-ciri gaya kepemimpinan kompromi adalah:

a. Memuaskan atasan dengan hasil kerja baik.

b. Memperhitungkan kerugiakan dan keuntungan.

c. Hubungan antar anggota terjalin baik

8. Pembangkang (Deserter)

Ciri-ciri gaya kepemimpinan

pembangkang adalah:

a. Menghindari tugas. b. Tidak suka berhubungan dengan anggota.

c. Kerap menghiraukan perintah dari atasan.

\section{Tipe Kepemimpinan Pendidikan Islam}

Tipe kepemimpinan pendidikan merupakan sebuah asumsi pemimpin dalam bidang pendidikan tentang kepemimpinan dan kekuasaan yang menampakkan perilaku pemimpin, tabiat dan tindakan dari kegiatan pimpinan yang digalakkan dalam lembaga pendidikan atau unit administrasi pendidikan yang dipimpinnya akan mempengaruhi situasi kerja, moral kerja anggota staf, sifat hubungan-hubungan kemanusiaan diantara sesamanya dan dapat mempengaruhi keberhasilan tujuan dari lembaga atau unit administrasi pendidikan. (Indfrafachrudi, Dirawat dan Lamberi, $1983: 49)$.

Berlandaskan asumsi, perilaku, tabiat dan tindakan pemimpin dalam melakukan dan memajukan kegiatan, maka tipe kepemimpinan dalam pendidikan Islam dapat dibedakan menjadi otoriter, bebas dan demokratis. Sedangkan tipe kepemimpinan pendidikan Islam pelengkap yaitu diantaranya tipe pemimpin kharismatis, tipe pemimpin pengayom, tipe pemimpin ahli, tipe pemimpin organisatoris dan administrator, tipe pemimpin agitator.

a. Tipe Otoriter

Pada tipe kepemimpinan ini memiliki kriteria, penetapan kebijakan "policy" ditentukan pemimpin dan bawahan bertugas untuk mengorganisir tanpa koordinasi dengan pemimpin. Anggota harus menyepakati "policy" serta menyetujui pembagian tugas tanpa interupsi apapun. (Indfrafachrudi, 
Dirawat dan Lamberi, 1983 : 49). Anggota wajib melaksanakan tugas dengan taat dan loyal kepada pemimpin. Semua aturan dan perintah pemimpin dianggap keputusan dari organisasi atau lembaga kerja tersebut.

Dalam tipe kepemimpinan otoriter, pimpinan melihat bahwa ia menonjol dan merasa lebih baik dibandingkan bawahannya. Anggota dipandang rendah. Pemimpin menonjolkan dirinya yang paling berkuasa, pintar dan benar. Perintahnya tidak boleh ditolak, harus dipatuhi. (Nawawi, 1993: 161). Tipe kepemimpinan ini cenderung berdampak negatif dalam berjalannya organisasi termasuk dalam ranah pendidikan (Nawawi, 1993: 161):

1) Anggota menjadi followers, tidak memiliki inisiatif dan tidak berani memutuskan. Tipe ini, dapat mengubur kreativitas, anggota organisasi tidak mampu mengembangkan pekerjaannya.

2) Bekerja tidak tenang dan canggung karena dihantui rasa takut, terpaksa dan tertindas

3) Organisasi tidak berkembang dan tidak berkemajuan.

Realitanya meskipun anggota telah mengetahui kekurangan tipe kepemimpinan ini, tetapi mereka tetap menyetujui serta patuh. Hal ini dapat dikarenakan beberapa faktor (Asmara, 1985: hlm. 36-37):

1) Anggota memiliki asumsi bahwa tujuan yang ditetapkan pimpinan merupakan kebutuhan umat.

2) Percaya penuh pada kemampuan pemimpin bahwa akan berhasil mencapai tujuan.
3) Anggota kurang menguasai bidang sesuai pekerjaannya.

4) Khawatir dan was-was pada hukuman dari pimpinan yang akan diberikan jika tidak mentaati peraturan dan perintahnya.

Pemimpin bertipe otoriter dari sudut pandangan Islam tidak dapat diterima secara mutlak, sebab yang memiliki hak untuk menjadikan kepemimpinan adalah Allah Swt. (Nawawi, 1993: 164). Maka jika seorang hamba selaku pemimpin, akan mengaktualisasikan kepemimpinan Allah Swt, maka kepemimpinan tipe ini menjadi benar dan tidak dapat ditolak. Kepemimpinan spiritual itu diwujudkan dengan sepenuhnya mengharuskan manusia atau umat Islam untuk melaksanakan perintah dan meninggalkan larangan Allah SWT tanpa inisiatif, saran, gagasan, kreativitas dan lainlain.

b. Bebas (Laissez Faire)

Tipe kepemimpinan bebas kontra dengan kepemimpinan otoriter. Pemimpin dalam tipe ini menjadi simbol/perlambang organisasi.

Pada tipe kepemimpinan ini, atasan membebaskan anggota dalam prosedur pelaksanaan pekerjaan. Mereka membuat ketetapan, menetapkan langkah-langkah kerja, memutuskan anggota yang akan diajak bekerjasama. Dapat disimpulkan, ketetapan mengenai cara, strategi kerja dalam pemutusannya menjadi kebijakan anggota secara penuh.

1) Kegiatan dalam organisasi terlaksana sesuai dengan kehendak anggota. 
2) Pemimpin akan turun tangan apabila diminta oleh anggota staf.

3) Pendapat pemimpin tentang penilaian yang berupa kritikan atau pujian terhadap pribadi, prestasi kerja anggota, pelaksanaan rencana tidak difloorkan kecuali anggota yang meminta.

4) Mudah timbul berbagai efek negatif, karena pemimpin tidak berperan menyatukan, mengarahkan, mengkoordinir, dan menggerakkan berdasarkan konsep metode tertentu. Pemimpin dalam kepemimpinan bebas berasumsi bahwa kewajibannya mengawasi, memberi keleluasaan dan menyiapkan semua keperluan serta memfasilitasi anggotanya demi lancarnya kegiatan dalam organisasi. Keadaan ini yang dapat memicu permasalahan, diantaranya (Asmara, 1985: 37):

1) Munculnya kekeruhan dalam tubuh organisasi mengenai pekerjaan.

2) Muncul ketidakjelasan tugas dan kekuasaan

3) Gagasan terbuang sia-sia

4) Penyelesaian tugas tidak optimal Hadirnya tipe ini dalam kepemimpinan pendidikan Indonesia antara lain (Indfrafachrudi, Dirawat dan Busro Lamberi, 1983: 53) :

1) Kurang gairahnya pemimpin sebagai penanggung jawab inti dibandingkan berhasilnya mencapai tujuan suatu organisasi.
2) Kurang kompetensi dan kepiawaian pemimpin

3) hubungan antara pemimpin dan anggota tidak terjalin dengan baik.

c. Kepemimpinan demokratis

Kepemimpinan ini mengutamakan pada aspek manusia atau personal dalam sebuah organisasi. Dalam tipe ini setiap anggota diakui keberadaannya serta kapasitasnya sebagai factor utama yang menjadikan organisasi lebih maju dan berkembang. Maka dari itu tabiat yang menonjol pada pemimpin diantaranya melindungi, menyelamatkan serta meningkatkan dan mengembangkan organisasi serta perangai para pelaksana. (Nawawi, 1993: 169).

Menurut Kurt Lewin, pimpinan yang demokratis mengasumsikan ia menjadi bagian dari anggota dan mendapatkan tanggung jawab bersama melakukan tugas untuk keberhasilan tujuan. (Wahab dan Umiarso, 2011: hlm. 95). Kepemimpinan demokratis bersifat terbuka, dinamis, aktif dan terarah. Terbuka dalam mengembangkan dan memajukan organisasi. Arah dan tujuan jelas, dilihat dari pelaksanaan aktivitas sesuai program kerja dengan efektif dan efisien.

Dari uraian di atas dapat disimpulkan tipe kepemimpinan demokratis adalah tipe kepemimpinan yang mana pemimpin tidak bekerja sendiri, membagi tugas-tugas secara tuntas, selalu melibatkan anggota dalam pengambilan keputusan penting melalui rapat atau musyawarah, kemudian dalam bekerja tidak ada perasaan takut dan tertekan sedang pemimpin dihormati dan disegani. 
Kepemimpinan demokratis memihak pada kebutuhan anggota organisasi yang berlandaskan asas membela kebenaran dan keadilan demi tercapainya tujuan bersama. Asas tersebut sesuai pandangan Islam dimana memprioritaskan pada sikap yang dapat membedakan hal ihwal haq dan yang bathil. Sesuai dengan firman Allah SWT dalam Qur'an surat Al-Baqarah ayat 42

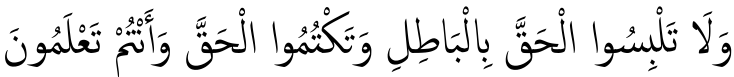

Artinya: Dan janganlah kamu campur adukkan yang hak dengan yang bathil dan janganlah kamu sembunyikan yang hak itu, sedang kamu mengetahui.

\section{d. Tipe Kepemimpinan Kharismatis}

Tipe kepemimpinan ini disimpulkan sebagai keahlian dalam memakai kestimewaan pada individu untuk mempengaruhi daya pikir, emosi dan tabiat orang lain, maka bathin mengagumi dan menghormati pimpinan kemudian mampu melaksanakan tugas sesuai kehendak pimpinan (Nawawi, 1993: hlm 175). Tipe ini mempunyai kemampuan, daya pikat dan wibawa sehingga dapat menarik pengikutnya (Mar'at, 1980: hlm 39-41).

Pemimpin dan kepemimpinannya dipandang istimewa karena sifat-sifat kepribadiannya yang mengagumkan dan berwibawa. Dalam kepribadian ini pemimpin diterima dan dipercayai sebagai orang yang dihormati, disegani dan dipatuhi/ditaati secara rela dan ikhlas.

Seorang pemimpin yang memiliki kharisma dan beriman, selalu menyadari dan mensyukuri kelebihan dalam kepribadiannya sebagai pemberian Allah SWT. Oleh karena itu akan selalu pula digunakannya untuk mengajak dan mendorong orang-orang yang dpimpinnya berbuat seseuatu yang dridhoi Allah SWT dalam rangka memakmurkan bumi, sebagai tugas kekhalifahannya yang telah difirmankan Allah SWT dalam surat AlAn'aam ayat 165

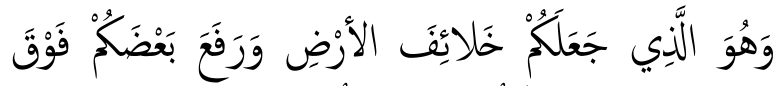

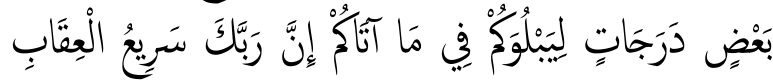

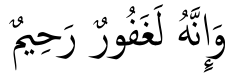

Artinya: Dan Dialah yang menjadikan Kamu penguasa-penguasa di bumi dan Dia meninggikan sebahagian kamu atas sebahagian (yang lain) beberapa derajat,untuk mengujimu tentang apa yang diberikan-Nya kepadamu. SesunggubnyaTuhanmu amat cepat siksaan-Nya, dan sesunggubnya Dia Maha Pengampun lagi Maha Penyayang. (AlQur'an dan terjemahannya, 2008)

e. Tipe Pemimpin Simbol

Pemimimpin hanya sekedar menjadi simbol atau perlambang dan tetap diakui sebagai pemimpin, meskipun tidak menjalankan fungsi kepemimpinnya. Tipe kepemimpinan ini cenderung pada kepemimpinan bebas (laissez faire) (Nawawi, 1993; 176)

Di dalam Al-Qur'an dapat ditemukan bagaiamana Allah SWT bermaksud memimpin manusia ke jalan yang benar, namun orang-orang kafir memilih kebebasan. Orang-orang tersebut hanya menempatkan Allah SWT sebagai simbol, sedang perbuatannya mendurhaka yang jauh dari tuntunan-Nya. Sebagaimana dengan firmanNya dalam surat An-Nahl ayat 37:

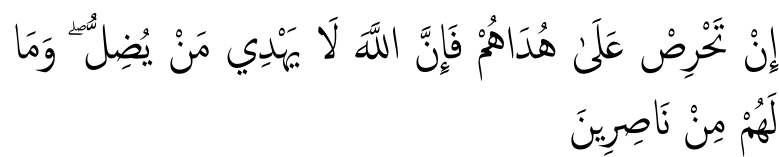

Artinya: Jika kamu sangat mengharapkan agar mereka dapat petunjuk, maka sesunggubnya Allah tiada memberi petunjuk kepada orang yang 
disesatkan-Nya, dan sekali-kali mereka tiada mempunyai penolong.

f. Tipe Pengayom (Headmanship)

Tipe ini mengidentikkan seorang pemimpin yang selalu bersedia melakukan semua tugas demi kebutuhan organisasi. Pemimpin yang selalu berada paling depan sebagai pelindung, pembela dan memiliki rasa juang yang tinggi demi kepentingan organisasi. Pemimpin dengan tipe ini sebagai orang beriman, dalam mengayomi, menjadi pelindung, pembela dan mampu berjuang demi kepentingan organisasi, menyadari bahwa keahliannya memiliki batas dan ia sadar bukan makhluk yang sempurna. Pimpinan menyadari pula bahwa Allah Swt yang sempurna untuk menjalankan segala sesuatu. Maka dari itu upayanya memihak pada kebenaran, sesuai dengan Qur'an surat An-Nisa' ayat 105 dan 107 (Nawawi, 1993: 177).

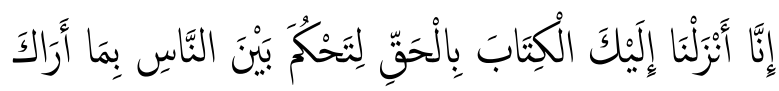

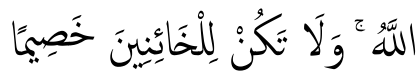

Artinya: Sesunggubnya Kami telah menurunkan kitab kepadamu dengan membawa kebenaran, supaya kamu mengadili antara manusia dengan apa yang telah Allah wabyukan kepadamu, dan janganlah kamu menjadi penantang (orang yang tidak bersalab), karena (membela) orang-orang yang k.hianat,
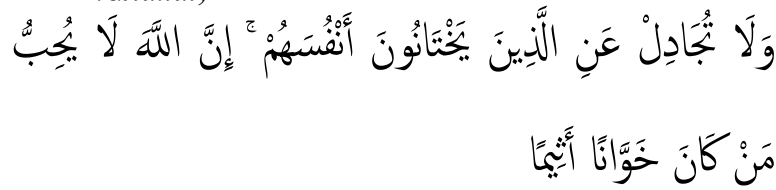

Artinya: Dan janganlab kamu berdebat (untuk. membela) orang-orang yang mengkbianati dirinya. Sesunggubnya Allah tidak menyukai orang-orang yang selalu berkhianat lagi bergelimang dosa,

\section{g. Tipe Pemimpin Ahli (Expert)}

Pada tipe ni, pemimimpin dipilih seseorang yang memiliki kreativitas serta kemampuan atau profesionalitas suatu bidang, melaksanakan kepemimpinan dalam lingkungan organisasi yang bergerak di bidang tersebut (Nawawi, 1993: 179). Keahlian atau profesionalisme itu mungkin diperoleh seseorang melalui bangku sekolah (pendidikan formal) atau pengalaman kerja atau berorganisasi. Dengan memiliki keahlian atau profesional di bidangnya itu, berarti pemimpin memiliki kelebihan untuk membimbing orangorang yang dipimpinnya melalui proses kerja sama yang efektif dan efisien. Semakin tinggi profesionalisme pemimpin, semakin mampu memikul dan mewujudkan tanggung jawab untuk berprestasi sesuai dengan firman Allah surat AlBaqarah 286.

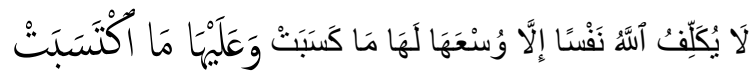

Artinya: Allah tidak membebani seseorang melainkan sesuai dengan kesanggupannya. Ia mendapat pabala (dari kebaikan) yang diusahakannya dan ia mendapat sikesa (dari kejahatan) yang dikerjakannya.

h. Tipe Organisatoris dan Administrator

Tipe ini ditunjukkan dengan keahlian mengelola serta mengkolaborasi pekerjaan dan melakukan aktivitas organisasi dengan tujuan yang jelas (Nawawi, 1993: 180). Pimpinan pada tipe ini dapat mengorganisir secara terencana, sistematis, tertib yang menerima berbagai saran dari anggota dalam maupun luar. Pemimpin mengetahui secara tepat posisi dan peranannya di dalam organisasinya dan selalu mampu mewujudkan kegiatan sesuai dengan posisi sebagaimana sudah diatur dalam Al-Qur'an pada surat AlAn'aam: 132: 


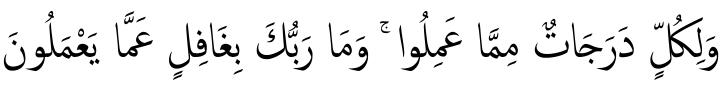

Artinya: Dan masing-masing orang memperoleh derajat-derajat (seimbang) dengan apa yang dikerjakannya. Dan Tubanmu tidak lengab dari apa yang mereka kerjakan. ( Al-Qur'aan dan Terjemahannya, 2013: 145)

i. Tipe Kepemimpinan Agitator

Pada tipe ini dilakukan dengan memberikan tekanan-tekanan, mengadu domba, menimbulkan dan mempertajam perselisihan, memecah belah dan menghasut anggota organisasi dengan maksud untuk memperoleh keuntungan bagi pimpinan dengan atau tanpa kelompoknya. Kepemimpinan ini sering ditemui di bidang politik kepartaian. Agitasi harus diwaspadai oleh para pemimpin Islam, karena tidak mustahil ada pemimpin agitator di dalam atau luar organisasinya. Sesuai dengan hal tersebut, Allah SWT berfirman dalam surat Al-Hasyr ayat 14 yang menggambarkan kondisi perpecahan.

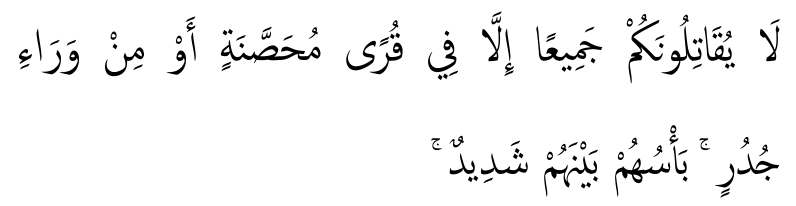

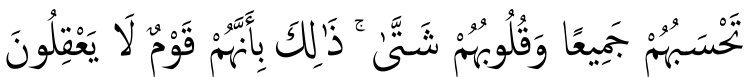

Artinya: Mereka tidak akan memerangi kamu (secara) bersama-sama, kecuali di negeri-negeri yang berbenteng atau di balik tembok. Permusuban antara sesama mereka adalab sangat hebat. Kamu kira mereka itu bersatu, padahal hati mereka terpecah belah. Yang demikian itu karena sesunggubnya mereka adalah kaum yang tidak mengerti. (Al-Qur'aan dan Terjemahannya, 2013: 54)

\section{KESIMPULAN}

Dalam mengklasifikasikan kepemimpinan, seorang pemimpin memiliki gayagaya memimpin yang mendasar. Gaya kepemimpinan ada beberapa macam di antaranya otokrasi, otokrasi yang disempurnakan, birokrat, pelindung dan penyelamat, mengembangkan dan memajukan organisasi, eksekutif, kompromi, pembelot.

Berdasarkan konsep, sifat, sikap dan caracara pemimpin itu melakukan serta memajukan organisasinya, sehingga dibagi menjadi tipe kepemimpinan pendidikan Islam yang utama diantaranya tipe kepemimpinan otoriter, bebas dan demokratis. Sedangkan tipe kepemimpinan pendidikan Islam pelengkap yaitu diantaranya tipe kepemimpinan kharismatis, tipe pengayom, tipe pimpinan ahli, tipe organisatoris dan administrator, tipe agitator.

\section{DAFTAR PUSTAKA}

Al-Ghazali, Al-Tibr Al-Masbuk fi Nasihat Al-Mulk, terjemah Ahmadie Thaha dan Ilyas Ismail, Nasihat Bagi Penguasa, cet. I. Bandung; Mizan.1994.

Al-Qur'an dan terjemahannya. 2008. Departemen Agama RI. Bandung: Diponegoro.

Al-Qur’an dan Terjemahannya. Jakarta: Pustaka Al-Mubin. 2013.

Asmara, Husna. Pengantar Kepemimpinan Pendidikan. Jakarta: Ghalia Indonesia. 1985.

Mar'at, Pemimpin dan kepemimpinan, (Bandung : Ghalia Indonesia, 1980.

Mertoprawiro, Soedarsono. Kepemimpinan, Bandingkan dengan Lembaga Administrasi Negara RI, Kepemimpinan. t.t: t.p., 1996.

Munawwir, Imam. Asas-Asas Kepemimpinan dalam Islam. Surabaya: Usana Offset. t.th.

Nanang, Fatah. Landasan Manaejemen Pendidikan. Bandung. Remaja Rosdakarya. 2011.

Nawawi,Hadari. Kepemimpinan Menurut Islam. Yogyakarta: Gadjah Mada University Press. 1993.

Rivai, Veithzal \& Arviyan Arifin, Islamic Leadership: Membangun Super Leadership Melalui Kecerdasan Spritual. Jakarta: Bumi Aksara, 2009. 
Rozak, Hefniy. Kepemimpinan Pendidikan dalam AlQur'an. Yogyakarta: Teras. 2014.

Sholeh, Abdul Rahman. Pendidikan Agama dan Pengembangn untuk Bangsa. Jakarta: PT. Raja Grafindo Persada, 2005.

Sjadzali, Munawir. Islam dan Tata Negara. Jakarta: UI Press. 1993.

Indfrafachrudi, Soekarto, Dirawat dan Busro Lamberi, Pengantar Kepemimpinan Pendidikan. Surabaya: Usana Offset. 1983.

Tim Penyusun Kamus Pusat Bahasa, Kamus Besar Bahasa Indonesia. Jakarta: Balai Pustaka. 2002.

Zainuddin, Mahli. Studi Kepemimpinan Islam. Yogyakarta; Al-Muhsin. 2002.

https://www.tribunnews.com/nasional/2019/03 /24/korupsi-korupsi-di-pusarankementerian-agama diakses pada tanggal 28 Agustus 2019.

https:// nasional.kompas.com/read/2019/04/08 /22375201/gubernur-aceh-irwandi-yusufdivonis-7-tahun-penjara?page $=$ all diakses pada tanggal 28 Agustus 2019.

https:// regional.kompas.com/read/2019/03/22 /22291211/korupsi-dana-bos-mantankepsek-dan-bendahara-di-bima-ditahan diakses pada tanggal 28 Agustus 2019.

https://www.bbc.com/indonesia/berita_indones ia/2016/10/161007_indonesia_ahok_lapo ran) akses pada tanggal 28 Agustus 2019 